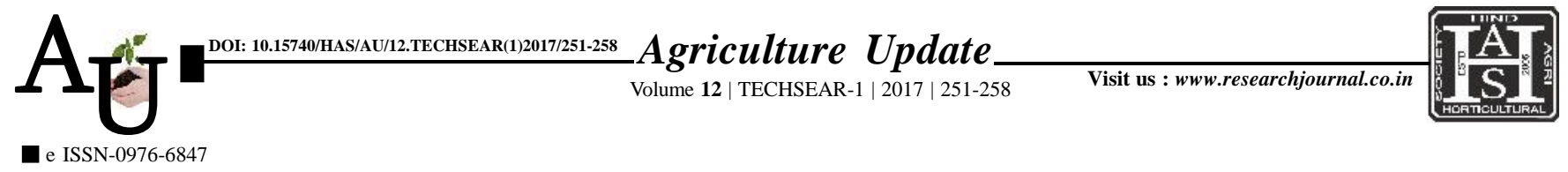

\title{
Research Article: Performance of BG-I and BG-II Bt cotton hybrids against mealybug Phenacoccus solenapsis Tinsley
}

A.G. BADGUJAR, B.B. BHOSLE AND M.M. SONKAMBLE

Article Chronicle :

Received :

11.07.2017;

Accepted :

26.07.2017

KeY WoRdS:

Mealy bug,

Phenacoccus

solenapsis Tinsley, Bt

cotton

Author for correspondence :

A.G. BADGUJAR

Department of

Agricultural

Entomology, Vasantrao

Naik Marathwada Krishi

Vidyapeeth, PARBHANI

(M.S.) INDIA

Email:anantbadgujar@

gmail.com

See end of the article for

authors' affiliations
SUMMARY : Among all Bt cotton hybrids mealy bug population ranged from 0.38 to 0.70 mealy bugs/ $2.5 \mathrm{~cm}$ shoot length. Minimum mealy bug population was observed on Paras Atal BG-I (0.38) which was at par with VBCH-1505 BG-I (0.49), Paras Brahma BG-I (0.39), ACH-155 BG-I (0.49), Ranjeet Bt BG-I (0.42 ), GK-205 BG-I (0.45), ACH-21-1 BG-I (0.41 ), SP-1037 BG-I (0.43), Mallika BG-II (0.49), Sigma BGII (0.49), TCH-4 BG-II (0.46 ), TCH-9 BG-II (0.42 ) and NSPL-9899 BG-II (0.44). Maximum mealy bug population was observed on VBCH-1006 BG-I (0.70), followed by ACH-177 BG-I (0.62), ACH-33 BG-I (0.59), Kanak BG-I (0.58), Cash BG-I (0.63), SP-499 BG-I (0.60 ), Bunny BG-II (0.64 ), VBCH-1505 BG-II (0.66), RCH-515 BG-II (0.64), VBCH-1501 BG-II (0.56), MRC-7326 BG-II (0.61 ), ACH-177 BG-II (0.61 ), ACH-11 BG-II (0.56), PRCH-505 BG-II (0.68) and NSPL-405 BG-II (0.60) which were at par with each others. The per cent plants infested by mealy bug on BG-I and BG-II Bt cotton ranged from 1.36 to 1.76 per cent. Among all Bt cotton hybrids (BG-I and BG-II) mealy bug infestation ranged from 1.33 to 1.76 per cent. Minimum mealy bug infestation was observed on Paras Atal BG-I (1.33) which was found significantly superior over rest of the hybrids except Paras Atal BG-I (1.36), ACH-21-1 BG-I (1.39) and TCH4 BG-II (1.40) which were at par and each others. Maximum mealy bug infestation was observed on VBCH-1006 BG-I (1.76) than rest of the hybrids.

How to cite this article : Badgujar, A.G., Bhosle, B.B. and Sonkamble, M.M. (2017). Performance of BG-I and BG-II Bt cotton hybrids against mealybug Phenacoccus solenapsis Tinsley. Agric. Update, 12(TECHSEAR-1) : 251-258; DOI: 10.15740/HAS/AU/12.TECHSEAR(1)2017/251-258. 